Уипурене Айсте Барбора

д-р пед. наук, преподаватель, лектор

Симанавичюс Матас

студент

Литовский университет спорта

г. Каунас, Литовская Республика

DOI $10.21661 / r-541400$

\title{
COMPETENCIES OF HEALTH EDUCATORS FOR SPORTS INJURY PREVENTION
}

Аннотация: основываясь на анализе научной литературы, авторами отмечено, что под руководством преподавателей, имеющчих высшее образование, риск получения травмы на тренировке снижен. Кроме того, вопросы образования преподавателей и качества тренировок, а также число и периодичность полученных клиентами спортивных травм в ходе тренировок освещуены в немногочисленных исследованиях. Цель работь - определить компетентность преподавателей физической культуры в вопросах предотвращеения спортивных травм.

Ключевые слова: спортивные травмы, преподавание физической культуры, компетенция, образование, профилактика.

Abstract: according to the analysis of literature, it can be stated in, that there is a lower risk of experiencing sports injury during training, working with such health educators who has higher education in sports science. It is also can be stated that there are few studies which would determine the education of health educators, the quality of training and sports injuries suffered by clients and their frequency during the conducted trainings (Waryasz, Daniels, Gil, Suric, \& Eberson, 2016). Research aim - to determine competencies of health educators for sports injury prevention.

Keywords: sports injuries, health educators, competence, education, prevention.

\section{Introduction}

According to the latest scientific literature, it can be stated in, that there is a lower risk of experiencing sports injury during training, working with such health educators 
who has higher education in sports science (Bianchi, Labbate, Castellana, Stefanizzi, De, Notarnicola, \& Tafuri, 2019). It is also can be stated that there are few studies which would determine the education of health educators, the quality of training and sports injuries suffered by clients and their frequency during the conducted trainings (Waryasz, Daniels, Gil, Suric, \& Eberson, 2016).

Research aim - to determine competencies of health educators for sports injury prevention.

Research tasks:

1. Investigate the knowledge of health educators about sports injury prevention;

2. Determine the nature and frequency of client injuries during the training;

3. To reveal the competencies of personal trainers in the aspects of gender and education.

\section{Methods}

The study involved 126 health educators: men $(n=84)$ and women $(n=42)$. After completing coaching courses $(n=63)$ and higher education $(n=51)$. To interview the subjects a questionnaire consisted of 19 statements was used. The statements were rated on a 5-point Likert scale, from 1 - strongly disagree to 5 - strongly agree.

\section{Results and Conclusions}

The study found that clients of health educators are most likely to experience tendon and muscle sprains and perturbations during training. These results are supported by research conducted by other authors who found that clients most often experience lumbar muscle sprains, tendon, and ankle sprains (Waryasz, Daniels, Gil, Suric, \& Eberson, 2016).

It was also found that the older a health educator is, the more often their clients experience sports injuries during training. After assessing the competencies of health educators in terms of gender and education, it was established that health educators with higher education:

- talk to clients more often about the most common sports injuries;

- performs basic exercises with clients;

- provides examples of why it is important to perform injury prevention exercises; 
- agree more that studies have acquired the knowledge and skills of sports injuries and how to avoid them;

- agrees that their clients experience less frequently tendon and muscle sprains.

These results are confirmed by other foreign authors who emphasize that educators who do not have a higher education in sports science are at a higher risk of causing sports trauma to their clients than those who have a higher education (Bianchi, Labbate, Castellana, Stefanizzi, De, Notarnicola, \& Tafuri, 2019).

Also, assessing the competencies of health educators from a gender perspective, we can say that men are more likely to experience tendon and muscle spasms, are more likely to lack knowledge about injury prevention, and are more likely to provide practical examples of injury prevention to female trainers.

\section{Список литературы}

1. Bianchi F.P. Epidemiology of injuries among amateur athletes who attended fitness activities: the role of the qualification of the trainer / F.P. Bianchi, M. Labbate, M. Castellana [et al.] // The Journal of sports medicine and physical fitness. - 2019. Vol. 60 (3). - P. 422-427.

2. Waryasz G.R. Personal trainer demographics, current practice trends and common trainee injuries / G.R. Waryasz, A.H. Daniels, J.A. Gil [et al.] // Orthopedic Reviews. - 2016. - Vol. 8 (3). - P. 95-105. 